\title{
RANCANGAN MODEL PENENTUAN UPAH MINIMUM KABUPATEN/PERKOTAAN (UMK/P) DI SUBOSUKAWONOSRATEN TAHUN 2006-2008
}

\author{
Sutomo \\ Yunastiti Purwaningsih ${ }^{1}$ \\ ${ }^{1}$ Fakultas Ekonomi Universitas Sebelas Maret Surakarta \\ E-mail: stmyst2000@yahoo.com
}

\begin{abstract}
This research aim is to compile design of calculation manual program of regency/city minimum wage (UMK) for worker paid attention various consideration, and agreed on by various relevant side in determination of minimum wage in Subosukawonosraten at period 2006-2008. This research is expected well for worker and for council of remunerating region as consideration material to all representatives of worker union and entrepreneur in determining proposal of regency and city minimum wage at period 2006-2008.

This research regarding base making of design model to determine $U M K / P$. Data that needed is KHM and KHL collected with survey method to merchants in some market in Subosukawonosraten, another data are inflation, PDRB, and labors amount from data publication of BPS Subosukawonosraten. Model used is projection method to determine level of UMK, the projection appropriate with Kepmenaker number 1, 1999, Permenaker number 17, 2005, and modification of model projection.

The result of this research is guide book of UMP/K determination which contain data, formula and its simulation, determination result of UMK for Subosukawonosraten region, and identify its supporting data.
\end{abstract}

Keywords: minimum wage, remunerate, design model

\section{PENDAHULUAN}

Selama akhir tahun 2005, terutama menjelang dan setelah ditetapkan usulan UMK tahun 2006 oleh Gubernur Jawa Tengah, demo buruh terjadi di sebagian wilayah propinsi ini antara lain di Semarang, Surakarta, Karanganyar, Pekalongan, Batang, Tegal, Brebes dan Demak (Kompas 22 Oktober 2005, Solopos 25 Oktober 2005 \& 1 Desember 2005). Pada umumnya para buruh menuntut diberlakukan UMK sama dengan nilai Kebutuhan Hidup Layak (KHL) sesuai ketentuan UU No 13/2003 tentang ketenagakerjaan maupun Permenaker No 17/2005 tentang komponen dan pelaksanaan tahapan pencapaian kebutuhan hidup layak pekerja, bahkan mereka meminta revisi terhadap keputusan Gubernur Jawa Tengah No.561/64/2005 tentang UMK tahun $2006 \mathrm{di}$ 35 Kabupaten/Kota. 
Di sisi lain pemerintah senantiasa berusaha memperbarui peraturan-peraturan tentang upah minimum, seperti mengesahkan dan memberlakukan Undang-Undang Republik Indonesia No.13 Tahun 2003 tentang Ketenagakerjaan, dimana bab X telah dengan tegas mengatur cara-cara perlindungan, pengupahan dan kesejahteraan tenaga kerja. Kemudian Permenaker No.1/1999 tentang UMR, Kepres 107/2004 tentang Dewan Pengupahan, serta Permenaker 17/2005 tentang Komponen Kebutuhan Hidup layak juga telah disahkan pemerintah untuk selanjutnya dilaksanakan.

Meskipun demikian, seiring dengan pembaharuan peraturan tentang upah minumum oleh pemerintah tersebut, belum pernah ada pedoman baku atau model cara penghitungannya sebagai acuan. Pedoman atau model yang dimaksud adalah petunjuk teknis maupun pelaksanaan yang sesuai dengan UU No. 13 tentang Ketenagakerjaan dan Permenaker No.1/1999, serta Permenaker 17/2005 tentang Komponen Kebutuhan Hidup layak. Keadaan ini menyebabkan timbulnya penafsiran yang berbeda antara pengusaha dan pekerja, sesuai dengan kepentingannya masing-masing. Perbedaan penafsiran tersebut diperkuat dengan belum berfungsinya secara optimal Dewan/Komisi Pengupahan Daerah.

Keadaan tersebut menimbulkan ketidakpuasan, terutama dari pihak pekerja yang menganggap upah tersebut masih terlalu rendah untuk dapat mencukupi kebutuhan minimum. Selanjutnya bagi pengusaha, terkadang penetapan besaran upah minimum dirasa terlalu tinggi dan memberatkan dengan keadaan seperti sekarang ini. Ketidakpuasan tersebut memunculkan respon negatif oleh kalangan pengusaha dan pekerja terhadap penetapan UMK oleh Gubernur, karena kurangnya keterbukaan latar belakang sebagai pertimbangan. Di lain pihak, penelitian mengenai upah minimum kota/kabupaten (UMK) jarang dilakukan, bahkan penelitian yang menghasilkan rancangan dalam bentuk program manual penghitungan UMK selama ini belum pernah ada.

Dengan latar belakang masalah tersebut, maka diperlukan adanya pedoman baku sebagai acuan dalam menghitung besaran UMK yang disepakati oleh pihak pengusaha dan pihak pekerja. Keadaan yang terjadi sekarang ini adalah masing-masing pihak dalam Tripartite menghitung besaran UMK dengan cara yang berbeda. Berdasar kondisi tersebut maka secara ringkas dapat disimpulkan inti dari masalah yang dihadapi adalah:

Rancangan model penentuan UMK yang bagaimana yang tepat, atau faktor-faktor apa sajakah yang sesuai untuk menentukan UMK, agar dapat memenuhi kesejahteraan pekerja tetapi tidak merugikan pengusaha.

Dengan demikian penelitian ini merupakan penelitian dasar pembuatan rancangan model penentuan UMK/P.

Langkah yang dilakukan dalam peneltian ini adalah (1) mengumpulkan data yang diperlukan, (2) menyusun draft buku pedoman penghitungan UMK, (3) mensimulasikan kepada dewan pengupahan daerah dan mahasiswa, serta (3) menyempurnakan draft buku pedoman dalam bentuk buku pedoman baku. Data yang diperlukan adalah KHM dan KHL yang dikumpulkan dengan metode survei terhadap pedagang di berbagai pasar sampel di wilayah Subosukawono- 
sraten. Survei dilakukan secara bersamasama oleh para perwakilan pengusaha industri, pekerja dan Komisi Pengupahan Daerah, serta unsur Tri Partite se eks Subosukawonosraten. Data lainnya adalah inflasi, PDRB, dan jumlah tenaga kerja yang merupakan publikasi Badan Pusat Statistik se Subosukawonosraten. Model yang digunakan adalah metode proyeksi untuk menghitung besaran UMK, proyeksi sesuai dengan rambu-rambu Kepmenaker No.1 tahun 1999, Permenaker No.17 tahun 2005, dan modifikasi model proyeksi.

\section{PEMBAHASAN}

Pembahasan meliputi rancangan model penentuan besaran UMK sebagai pedoman penghitungan besaran UMK dengan berbagai model proyeksi, dilengkapi dengan hasil perhitungan besaran UMK untuk wilayah Subosukawonosraten beserta data pendukungnya.

\section{Pedoman Perhitungan Besaran Upah Minimum}

Pedoman penghitungan besaran upah minimum (UMK) yang dituangkan dalam bentuk buku atau program manual berisi tentang (1) data yang diperlukan, (2) cara perhitungan, (3) simulasi perhitungan, dan (4) data sebagai pelengkap untuk latihan menghitung besaran upah minimum sesuai dengan rumus yang tertuang dalam buku pedoman. Secara garis besar program manual penghitungan UMK diurai di bawah ini.

\section{Data}

Data yang diperlukan untuk menghitung UMK meliputi:
1) Upah Minimum Kabupaten/Kota satu tahun sebelumnya

2) Kebutuhan Hidup Minimum satu tahun sebelumnya dan tahun sekarang

3) PDRB satu tahun sebelumnya dan tahun sekarang (dengan catatan apabila data satu tahun sebelumnya belum dipublikasikan, maka menggunakan data dua tahun sebelumnya)

4) Inflasi satu tahun sebelumnya dan tahun sekarang

5) Kebutuhan Hidup Layak satu tahun sebelumnya dan tahun sekarang

6) Kesempatan kerja satu tahun sebelumnya dan tahun sekarang (dengan catatan apabila data satu tahun sebelumnya belum dipublikasikan, maka menggunakan data dua tahun sebelumnya)

\section{Cara perhitungan}

Perhitungan besaran UMK dilakukan dengan tiga cara, yaitu perhitungan dengan proyeksi sesuai Kepmenaker No.1/1999 tentang UMR, proyeksi sesuai Permenaker 17/2009 dan modifikasi model proyeksi.

\section{1) Perhitungan proyeksi sesuai Kepmenaker No. 1/1999}

Perhitungan proyeksi besaran upah minimum sesuai dengan Kepmenaker No.1/1999, merupakan proyeksi dengan dua jenis data dasar, yaitu:

a) Besaran upah minimum kabupaten/ kota satu tahun sebelumnya yang ditetapkan Pemerintah daerah (pemda)

b) Besaran kebutuhan hidup minimum satu tahun sebelumnya

Perhitungan besaran upah minumum dengan dua jenis data dasar tersebut dengan variabel pertimbangan sebagai berikut: 
a) Pertumbuhan sektor industri satu tahun sebelumnya

b) Perkembangan kebutuhan hidup minimum satu tahun sebelumnya

c) Tingkat inflasi tahun sekarang

Rumus perhitungan masing-masing proyeksi sebagai berikut:

a) Data dasar adalah upah minimum kabupaten/kota satu tahun sebelumnya yang ditetapkan Pemda

(1) Variabel pertimbangan adalah pertumbuhan sektor industri

$\mathrm{UMK}_{\mathrm{t}}=\mathrm{UMK}_{\mathrm{t}-1} \times\left(1+\mathrm{R} \operatorname{Ind}_{\mathrm{t}-2}\right)$

$R \operatorname{Ind}_{\mathrm{t}-2}=\left\{\left(\operatorname{Ind}_{\mathrm{t}-2}-\operatorname{Ind}_{\mathrm{t}-3}\right) / \operatorname{Ind}_{\mathrm{t}-3}\right\} \mathbf{x}$ $100 \%$

(2) Variabel pertimbangan adalah tingkat perkembangan KHM

$\mathrm{UMK}_{\mathrm{t}}=\mathrm{UMK}_{\mathrm{t}-1} \times\left(1+\mathrm{R} \mathrm{KHM}_{\mathrm{t}-1}\right)$

$\mathrm{R} \mathrm{KHM}_{\mathrm{t}-1}=\left\{\left(\mathrm{KHM}_{\mathrm{t}-1}-\mathrm{KHM}_{\mathrm{t}-2}\right)\right\}$

$$
\text { KHM } \left._{t-2}\right\} \times 100 \%
$$

(3) Variabel pertimbangan adalah tingkat inflasi

$\mathrm{UMK}_{\mathrm{t}}=\mathrm{UMK}_{\mathrm{t}-1} \times\left(1+\mathrm{NF}_{\mathrm{t}-1}\right)$

b) Data dasar adalah kebutuhan hidup minimum satu tahun sebelumnya

(1) Variabel pertimbangan adalah pertumbuhan sektor industri

$\mathrm{UMK}_{\mathrm{t}}=\mathrm{UMK}_{\mathrm{t}-1} \times\left(1+\mathrm{R}\right.$ Ind $\left._{\mathrm{t}-2}\right)$

$R \operatorname{Ind}_{t-2}=\left\{\left(\operatorname{Ind}_{t-2}-\operatorname{Ind}_{t-3}\right) / \operatorname{Ind}_{t-3}\right\} x$

$$
100 \%
$$

(2) Variabel pertimbangan adalah tingkat perkembangan $\mathrm{KHM}$

$\mathrm{UMK}_{\mathrm{t}}=\mathrm{UMK}_{\mathrm{t}-1} \times\left(1+\mathrm{R} \mathrm{KHM}_{\mathrm{t}-1}\right)$
$\mathrm{R} \mathrm{KHM}_{\mathrm{t}-1}=\left\{\left(\mathrm{KHM}_{\mathrm{t}-1}-\mathrm{KHM}_{\mathrm{t}-2}\right)\right\}$ $\left.\mathrm{KHM}_{\mathrm{t}-2}\right\} \times 100 \%$

(3) Variabel pertimbangan adalah tingkat inflasi

$\mathrm{UMK}_{\mathrm{t}}=\mathrm{UMK}_{\mathrm{t}-1} \times\left(1+\mathrm{NF}_{\mathrm{t}-1}\right)$

Keterangan rumus :

$\mathrm{UMK}_{\mathrm{t}} \quad=\quad \mathrm{UMK}$ hasil perhitungan tahun $\mathrm{t}$

UMK $_{\mathrm{t}-1}=$ Besarnya UMK tahun $\mathrm{t}-1$

R Ind I $_{\mathrm{t} 2} \quad=\quad$ Tingkat pertumbuhan sektor industri pada tahun $\mathrm{t}-2 \mathrm{~s}$

Ind $_{\mathrm{t}-2}=$ Sumbangan sektor industri terhadap PDRB tahun $\mathrm{t}-2$

Ind $_{\mathrm{t}-3}=$ Sumbangan sektor industri terhadap PDRB tahun t-3

$\mathrm{RKHM}_{\mathrm{t}-1}=$ Tingkat perkembangan $\mathrm{KHM}$ t-I

$\mathrm{KHM}_{\mathrm{t}-1}=$ KHM tahun $\mathrm{t}-1$

$\mathrm{KHM}_{\mathrm{t}-2}=\mathrm{KHM}$ tahun $\mathrm{t}-2$

$\mathrm{INF}_{\mathrm{t}-1}=$ Tingkat inflasi pada tahun $\mathrm{t}-1$

2) Perhitungan proyeksi sesuai

Permenaker 17/ 2005

Besaran upah minimum sesuai dengan Permenaker 17/2005 tentang KHL, diberlakukan untuk menghitung UMK tahun 2007. Perhitungan proyeksi besaran upah minimum sesuai dengan Permenaker ini menyatakan bahwa besaran upah minimum didasarkan di antaranya pada tahap pencapaian KHL, pertumbuhan PDRB, produktivitas, dan mempertimbangkan keberadaan sektor marjinal (usaha yang paling tidak mampu).

Pada pelaksanaannya, pertimbangan pada usaha tidak mampu ternyata belum dapat dioperasionalkan, maka untuk kepentingan perhitungan dapat diabaikan. Dengan demikian besaran upah minimum dihitung berdasar tahap pensapaian $\mathrm{KHL}$, 
produktivitas, dan pertumbuhan PDRB, rumus perhitungan sebagai berikut:

a) $\mathrm{KHL}$

$\mathrm{UMK}_{\mathrm{t}}=\mathrm{a} \times \mathrm{KHL}_{\mathrm{t}-1}$

b) Pertumbuhan Ekonomi

$U M K_{t}=U M K_{t-1} \times(1 \times$ Pertumbuhan

PDRBt-2)

Pertumbuhan PDRB $_{\mathrm{t}-2}=$

$$
\begin{aligned}
& \left\{\left(\mathrm{PDRB}_{\mathrm{t}-2}-\mathrm{PDRB}_{\mathrm{t}-3}\right) /\right. \\
& \text { PDRB } \left._{\mathrm{t}-3}\right\} \times 100 \%
\end{aligned}
$$

c) Produktivitas

$\mathrm{UMK}_{\mathrm{t}}=\mathrm{UMK}_{\mathrm{t}-1} \times(1 \times$ Pertumbuhan

$$
\text { Prodktvas }_{\mathrm{t}-2} \text { ) }
$$

Pertumbuhan Prodktvas $_{\mathrm{t}-1}=$

$\left\{\right.$ Prodktvas $_{\mathrm{t}-2}-$ Prodktvas $_{\mathrm{t}-3}$ /

Prodktvas $\left.\left._{\mathrm{t}-3}\right)\right\} \times 100 \%$

Prodktvas $_{\mathrm{t}-2}=$ PDRB $_{\mathrm{t}-2} / \mathrm{KK}_{\mathrm{t}-2}$

Prodktvas $_{\mathrm{t}-3}=$ PDRB $_{\mathrm{t}-3} / \mathrm{KK}_{\mathrm{t}-3}$

d) Gabungan

$\mathrm{UMK}_{\mathrm{t}}=\mathrm{UMK}_{\mathrm{t}-1}(1 \times \mathrm{R}$ Gabungan $)$

R gabungan $=$ (pertumbuhan

Prodktvas $_{\mathrm{t}-2}+$ pertumbuhan

$\left.\mathrm{PDRB}_{\mathrm{t}-2}+\mathrm{INF}_{\mathrm{t}-1}\right) / 3$

\section{Keterangan:}

$\mathrm{UMK}_{\mathrm{t}}$

A

UMK $_{\mathrm{t}-1}=$ UMK tahun $\mathrm{t}-1$

$\mathrm{KHL}_{\mathrm{t}-1} \quad=\quad$ Besarnya KHL tahun t-1

Pertumbuhan $=$ Tingkat pertumbuhan

\begin{tabular}{|c|c|c|}
\hline PDRB $_{t-3}$ & $=$ & $\begin{array}{l}\text { Besarnya PDRB tahun } \\
\mathrm{t}-3\end{array}$ \\
\hline $\begin{array}{l}\text { Pertumbuhan } \\
\text { Prodktvtas }_{\mathrm{t}-2}\end{array}$ & $=$ & $\begin{array}{l}\text { Tingkat pertumbuhan } \\
\text { Produktivitas tahun } t-2\end{array}$ \\
\hline Prodktvas $_{t-2}$ & $=$ & Produktivitas tahun $\mathrm{t}-2$ \\
\hline Prodktvas $_{\mathrm{t}-3}$ & $=$ & Produktivitas tahun $\mathrm{t}-3$ \\
\hline$K K_{t-2}$ & $=$ & $\begin{array}{l}\text { Kesempatan Kerja } \\
\text { tahun } t-2\end{array}$ \\
\hline $\mathrm{KK}_{\mathrm{t}-3}$ & $=$ & $\begin{array}{l}\text { Kesempatan Kerja } \\
\text { tahun t-3 }\end{array}$ \\
\hline $\mathrm{INF}_{\mathrm{t}-1}$ & $=$ & $\begin{array}{l}\text { Tingkat inflasi pada } \\
\text { tahun } t-1\end{array}$ \\
\hline
\end{tabular}

PDRB $_{\mathrm{t}-2} \quad$ PDRB tahun t-2

PDRB $_{\mathrm{t}-2}=$ Besarnya PDRB tahun

\section{3) Modifikasi model proyeksi}

Penghitungan besaran upah minimum sesuai dengan Permenaker 17/2005 menggunakan dasar perhitungan KHL, pertumbuhan ekonomi dan produktivitas, dimana kesemuanya menggunakan besaran tahun lalu. Penelitian ini membuat modifikasi model proyeksi, yaitu dengan dasar perhitungan adalah tahapan pencapaian KHL pada tahun yang sama dengan tahun besaran UMK yang ditentukan, sebagai misal besaran UMK 2007 dihitung berdasar KHL tahun 2007.

Perhitungan besaran KHL pada tahun tersebut dengan menggunakan laju inflasi pada tahun yang sedang berjalan, sehingga besaran KHL pada tahun 2007 merupakan besaran KHL 2006 dengan memperhitungkan laju inflasi pada tahun 2006. Selanjutnya dengan data dasar pencapaian tahapan KHL tersebut, dilakukan proyeksi besaran UMK dengan variabel pertimbangan adalah pertumbuhan ekonomi dan produktivitas.

Pertimbangan terhadap penggunaan angka KHL tahun berjalan adalah sebagai langkah menggabungkan pertimbangan ekonomi dan non ekonomi yang berupa opini publik yang dimuat melalui media cetak 
ataupun elektronik. Sebagai contoh adalah pemberitaan di media yang menulis bahwa: (1) serikat buruh minta UMK tahun depan harus sama dengan KHL; (2) berdasarkan statistik industri pengusaha mengekspose adanya PHK besar-besaran di sejumlah pabrik karena situasi perekonomian, dan (3) pentingnya peran media dalam ekspose berita tentang UMK saat sedang dalam proses perhitungan untuk diusulkan, hingga penetapan dan pascapenetapan oleh gubernur di berbagai propinsi.

Modifikasi model proyeksi seperti yang telah diurai di atas, menggunakan rumus perhitungan sebagai berikut:

a) $\mathrm{KHL}$

$$
\begin{aligned}
& \mathrm{UMK}_{\mathrm{t}}=\mathrm{ax} \mathrm{KHL}_{\mathrm{t}} \\
& \mathrm{KHL}_{\mathrm{t}}=\mathrm{KHL}_{\mathrm{t}-1} \times\left(1+\mathrm{NF}_{\mathrm{t}-1}\right)
\end{aligned}
$$

b) Pertumbuhan Ekonomi

$\mathrm{UMK}_{\mathrm{t}}=\mathrm{a} \times \mathrm{KHL}_{\mathrm{t}} \times(1 \times$ Pertumbuhan PDRB $_{\mathrm{t}-2}$ )

Pertumbuhan PDRB $_{\mathrm{t}-2}=\left\{\left(\mathrm{PDRB}_{\mathrm{t}-2}-\right.\right.$ $\left.\mathrm{PDRB}_{\mathrm{t}-3} / \mathrm{PDRB}_{\mathrm{t}-3}\right\} \times 100$

c) Produktivitas

$\mathrm{UMK}_{\mathrm{t}}=\mathrm{a} \times \mathrm{KHL}_{\mathrm{t}} \times(1 \times$ Pertumbuhan Prodktvas t-2)

Pertumbuhan Prodktvas ${ }_{\mathrm{t}-2}=$ $\left\{\right.$ Prodktvas $_{\mathrm{t}-2}-$ Prodktvas $_{\mathrm{t}-3}$ ' Prodktvas $\left._{\mathrm{t}-3}\right\} \times 100$

Prodktvas $_{\mathrm{t}-2}=$ PDRB $_{\mathrm{t}-2} / \mathrm{KK}_{\mathrm{t}-2}$ Prodktvas $_{\mathrm{t}-3}=\mathrm{PDRB}_{\mathrm{t}-3} / \mathrm{KK}_{\mathrm{t}-3}$

d) Gabungan

$\mathrm{UMK}_{\mathrm{t}}=\mathrm{a} \times \mathrm{KHL}_{\mathrm{t}} \times\left(1 \times \mathrm{R}\right.$ Gabungan $\left._{\mathrm{t}-2}\right)$ Rgabungan $=\left(\right.$ pertumbuhan prodktvas $_{\mathrm{t}-2}$ + pertumbuhan $\mathrm{PDRB}_{\mathrm{t}-2}+$ $\left.\mathrm{INF}_{\mathrm{t}-1}\right) / 3$

\begin{tabular}{|c|c|c|}
\hline $\mathrm{UMK}_{\mathrm{t}}$ & $=$ & $\begin{array}{l}\text { UMK hasil perhitungan } \\
\text { tahun } t\end{array}$ \\
\hline A & $=$ & $\begin{array}{l}\text { Tahap capaian KHL: } \\
90 \%, 95 \%\end{array}$ \\
\hline $\mathrm{KHL}_{\mathbf{t}}$ & $=$ & Besarnya KHL tahun $t$ \\
\hline $\mathrm{KHL}_{\mathrm{t}-1}$ & $=$ & Besarnya KHL tahun $\mathrm{t}-1$ \\
\hline$I N F_{t-1}$ & $=$ & Inflasi tahun $\mathrm{t}-1$ \\
\hline $\begin{array}{l}\text { Pertumbuhan } \\
\text { PDRB }_{\mathrm{t}-2}\end{array}$ & $=$ & $\begin{array}{l}\text { Tingkat pertumbuhan } \\
\text { PDRB tahun } \mathrm{t}-2\end{array}$ \\
\hline PDRB $_{\mathrm{t}-2}$ & $=$ & Besarnya PDRB tahun $\mathrm{t}-2$ \\
\hline $\mathrm{PDRB}_{\mathrm{t}-3}$ & $=$ & Besarnya PDRB tahun $t-3$ \\
\hline $\begin{array}{l}\text { Pertumbuhan } \\
\text { Prodktvtas }_{\mathrm{t}-2}\end{array}$ & $=$ & $\begin{array}{l}\text { Tingkat pertumbuhan } \\
\text { Produktivitas tahun } \\
\text { t-2 }\end{array}$ \\
\hline Prodktvas $_{\mathrm{t}-2}$ & $=$ & $\begin{array}{l}\text { Produktivitas tahun } \\
\text { t-2 }\end{array}$ \\
\hline Prodktvas $_{\mathrm{t}-3}$ & $=$ & $\begin{array}{l}\text { Produktivitas tahun } \\
t-3\end{array}$ \\
\hline $\mathrm{KK}_{\mathrm{t}-2}$ & $=$ & $\begin{array}{l}\text { Kesempatan Kerja tahun } \\
\mathrm{t}-2\end{array}$ \\
\hline $\mathrm{KK}_{\mathrm{t}-3}$ & $=$ & $\begin{array}{l}\text { Kesempatan Kerja tahun } \\
\text { t-3 }\end{array}$ \\
\hline
\end{tabular}

\section{Keterangan:}

\section{Simulasi Perhitungan}

Simulasi perhitungan besaran UMK merupakan penerapan dari rumus perhitungan yang telah diurai di atas, dan diambil sebagai contoh adalah menghitung besaran UMK Surakarta. Dalam laporan penelitian tersaji simulasi perhitungan lengkap dengan tiga model proyeksi: Kepmenaker No. 1/1999, Permenaker No.17/ 2005 dan modifikasi model proyeksi. Dalam artikel ilmiah ini diambil salah satu perhitungan proyeksi sesuai Kepmenaker No. 1/1999, yaitu penentuan besaran UMK dengan data dasar adalah upah minimum kabupaten/ kota satu tahun sebelumnya yang ditetapkan Pemda. Dengan data dasar tersebut, maka dihitung proyeksi besaran UMK dengan variabel pertimbangan pertumbuhan sektor industri, perkembangan 
KHM dan inflasi. Berikut adalah perhitungan besaran UMK yang dimaksud.

1. Variabel pertimbangan adalah pertumbuhan sektor industri

a) Rumus

Rumus umum:

$$
\begin{gathered}
\mathrm{UMK}_{\mathrm{t}}=\mathrm{UMK}_{\mathrm{t}-1} \mathrm{x}\left(1+\mathrm{R} \operatorname{Ind}_{\mathrm{t}-2}\right) \\
\mathrm{R} \operatorname{Ind}_{\mathrm{t}-2}=\underset{\mathrm{t}}{\left\{\left(\operatorname{Ind}_{\mathrm{t}-1}-\operatorname{Ind}_{\mathrm{t}-2}\right) / \operatorname{Ind}_{\mathrm{t}-2}\right\} \mathrm{x}} \\
100 \%
\end{gathered}
$$

Penerapan rumus umum:

$$
\begin{aligned}
\text { UMK } 2006= & \text { UMK } 2005 \times(1+R \text { Ind } \\
& 2004) \\
\text { R Ind } 2004= & \{(\text { Ind } 2004-\text { Ind } 2003) / \\
& \text { Ind } 2003\} \times 100 \%
\end{aligned}
$$

b) Data

UMK 2005 adalah besaran upah minimum tahun $2005=\operatorname{Rp} 427.000$

$\mathbf{R}$ Ind adalah pertumbuhan sumbangan sektor industri terhadap PDRB dari tahun 2003-2004:

$$
\begin{aligned}
& \text { Ind } 2003=\text { Sumbangan sektor } \\
& \text { industri tahun } 2003 \\
& =\operatorname{Rp} 378.537,14 \text { (dalam } \\
& \text { juta) } \\
& \text { Ind } 2004=\text { Sumbangan sektor } \\
& \text { industri tahun } 2004 \\
& =\operatorname{Rp} 400.992,01 \text { (dalam } \\
& \text { juta) } \\
& \mathrm{R} \text { Ind } 2004=\{(\operatorname{Ind} 2004-\operatorname{Ind} 2003) / \\
& \text { Ind 2003\} x 100\% } \\
& =\{(\operatorname{Rp} 400.992,01- \\
& \text { Rp 378.537,14/ } \\
& \operatorname{Rp} 378.537,14\} \times 100 \% \\
& =5,93 \% \text { atau } 0,0593
\end{aligned}
$$

c) Perhitungan

$$
\begin{aligned}
\text { UMK } 2006= & \text { UMK } 2005 \times(1+ \\
& \text { R Ind 2004 }) \\
= & \operatorname{Rp~427.000\times (1+~} \\
& 0,0593) \\
= & \operatorname{Rp~452.321~}
\end{aligned}
$$

UMK $2006=$ Rp. 427.000

2. Variabel pertimbangan adalah tingkat perkembangan KHM

a) Rumus

Rumus umum:

$$
\begin{aligned}
& \mathrm{UMK}_{\mathrm{t}}=\mathrm{UMK}_{\mathrm{t}-\mathrm{I}} \times\left(1+\mathrm{R} \mathrm{KHM}_{\mathrm{t}}\right) \\
& \mathrm{RKHM}=\left\{\left(\mathrm{KHM}_{\mathrm{t}}-\mathrm{KHM}_{\mathrm{t}-1}\right) /\right. \\
&\left.\mathrm{KHM}_{\mathrm{t}-1}\right\} \times 100 \%
\end{aligned}
$$

Penerapan rumus umum:

$$
\begin{aligned}
& \text { UMK } 2006=\text { UMK } 2005 \times(1+ \\
& \text { R KHM 2005) } \\
& \begin{aligned}
\text { R KHM } 2005= & \{(\text { KHM } 2005-\text { KHM } \\
& 2004) / \text { KHM 2004 }\} \times \\
& 100 \%
\end{aligned}
\end{aligned}
$$

b) Data

UMK 2005 adalah besaran upah minimum tahun $2005=\operatorname{Rp} 427.000$

R KHM 2005 adalah tingkat perkembangan KHM tahun 2004-2005:

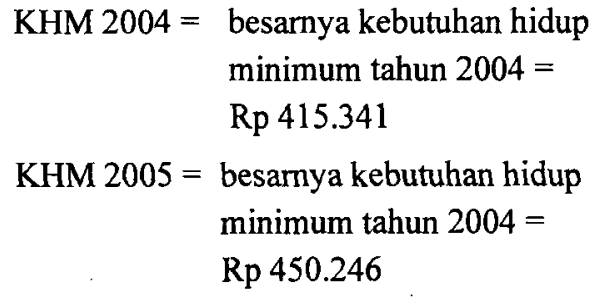




$$
\begin{aligned}
\text { R KHM 2005 }= & \{(\text { KHM 2005 }- \text { KHM } \\
& 2004) / \text { KHM 2004 }\} \times \\
& 100 \% \\
= & \{(\text { KHM } 2005-\text { KHM } \\
& 2004) / \text { KHM } 2004\} \times \\
& 100 \% \\
= & 8,40 \% \text { atau } 0,0840
\end{aligned}
$$

c) Perhitungan

$$
\begin{aligned}
\text { UMK2006 }= & \text { UMK2005 } \times(1+\mathrm{R} \mathrm{KHM} \\
& 2005) \\
= & \operatorname{Rp} 427.000 \times(1+0,0840) \\
= & \operatorname{Rp} 462.868
\end{aligned}
$$

UMK 2006 $=$ Rp. 462.868

3. Variabel pertimbangan adalah tingkat inflasi

a) Rumus

Rumus umum:

$$
\mathrm{UMK}_{\mathrm{t}}=\mathrm{UMK}_{\mathrm{t}-1} \times\left(1+\mathrm{NNF}_{\mathrm{t}-1}\right)
$$

Penerapan rumus umum:

UMK2006 = UMK $2005 \times(1+$ INF2005)

b) Data

UMK2005 adalah besaran upah minimum tahun $2005=\operatorname{Rp} 427.000$

INF 2005 adalah tingkat inflasi tahun $2005=1,1 \%$ atau 0,011

c) Perhitungan

$$
\begin{aligned}
\text { UMK2006 }= & \text { UMK 2005 } \times(1+ \\
& \text { INF2005) } \\
= & \text { Rp } 427.000 \times(1+0,011) \\
= & \text { Rp. } 431.697
\end{aligned}
$$

UMK 2006 = Rp. 431.697

\section{Hasil Perhitungan Proyeksi Besaran Upah Minimum}

Hasil perhitungan besaran upah minimum (UMK) tahun 2006 untuk wilayah Subosukawonosraten dengan metode proyeksi seperti dirumuskan dalam pedoman penghitungan UMK tersebut di atas disajikan di bawah ini. Perhitungan secara rinci dapat dilihat laporan hasil penelitian pada lampiran perhitungan besaran UMK tahun 2006 dan tahun 2007.

\section{Perhitungan proyeksi sesuai Kepme- naker No. 1/1999}

Hasil perhitungan proyeksi besaran upah minimum sesuai dengan Kepmenaker No.1/1999 disajikan dalam tabel 1, dimana perhitungan ini merupakan proyeksi dengan dua jenis data dasar, yaitu:

1) Besaran upah minimum kabupaten/kota satu tahun sebelumnya yang ditetapkan Pemda.

2) Besaran kebutuhan hidup minimum satu tahun sebelumnya

Perhitungan besaran upah minumum dengan dua jenis data dasar tersebut dengan variabel pertimbangan sebagai berikut:

1) Pertumbuhan sektor industri satu tahun sebelumnya

2) Perkembangan kebutuhan hidup minimum satu tahun sebelumnya

3) Tingkat inflasi tahun sekarang

\section{Perhitungan proyeksi sesuai Permena- ker 17/2005}

Hasil perhitungan proyeksi besaran upah minimum sesuai dengan Permenaker No.17/2005 disajikan dalam tabel 2 . Penghitungan proyeksi besaran upah minimum sesuai dengan Permenaker ini dihitung berdasar tahap pencapaian KHL, produktivitas, dan pertumbuhan PDRB. 
Tabel 1. Besaran UMK 2006 Hasil Proyeksi Sesuai Kepmenaker No. 1/1999 Menurut Kabupaten/Kota di Wilayah Eks Karesidenan Surakarta

\begin{tabular}{|c|c|c|c|c|c|c|}
\hline \multirow{3}{*}{$\begin{array}{l}\text { Kabupaten/ } \\
\text { Kota }\end{array}$} & \multicolumn{6}{|c|}{ Besaran UMK (Rp/bulan) } \\
\hline & \multicolumn{3}{|c|}{$\begin{array}{c}\text { UMK } 2005 \\
\text { Sebagai Dasar Perkiraan }\end{array}$} & \multicolumn{3}{|c|}{$\begin{array}{c}\text { KHM } 2005 \\
\text { Sebagai Dasar Perkiraan }\end{array}$} \\
\hline & $\begin{array}{c}\text { Pertumbuhan } \\
\text { Industri }\end{array}$ & $\begin{array}{c}\text { Pertumbuhan } \\
\mathrm{KHM}\end{array}$ & Inflasi & $\begin{array}{l}\text { Pertumbuhan } \\
\text { Industri }\end{array}$ & $\begin{array}{c}\text { Pertumbuhan } \\
\text { KHM }\end{array}$ & Inflasi \\
\hline Surakarta & 452,321 & 462,868 & 431,697 & 476,946 & 488,067 & 455,199 \\
\hline Boyolali & 418,121 & 421,301 & 417,832 & 411,944 & 415,077 & 411,659 \\
\hline Sukoharjo & 429,593 & 405,324 & 421,962 & 392,717 & 370,531 & 385,741 \\
\hline Karanganyar & 440,286 & 426,426 & 424,788 & 431,846 & 418,252 & 416,645 \\
\hline Wonogiri & 430,076 & 395,282 & 411,400 & 435,098 & 399,897 & 416,204 \\
\hline Sragen & 434,176 & 432,146 & 410,588 & 452,148 & 450,034 & 427,583 \\
\hline Klaten & 430,295 & 404,711 & 415,494 & 420,068 & 395,092 & 405,618 \\
\hline Rata-rata & 414,337 & 421,059 & 414,193 & 405,440 & 412,018 & 405,299 \\
\hline
\end{tabular}

Sumber: Laporan Hasil Penelitian pada Lampiran Perhitungan Proyeksi Besaran UMK Tahun 2006. Perhitungan 1 dan 2.

Tabel 2. Besaran UMK 2006 Hasil Proyeksi Sesuai Permenaker No. 17/2005 Menurut Kabupaten/Kota di Wilayah Eks Karesidenan Surakarta

\begin{tabular}{|c|c|c|c|c|}
\hline \multirow{2}{*}{ Kab./Kota } & \multicolumn{4}{|c|}{ Besaran UMK (Rp/bulan) } \\
\hline & $\begin{array}{c}\text { Pencapaian } \\
90 \% \mathrm{KHL}\end{array}$ & $\begin{array}{l}\text { Pertumbuhan } \\
\text { Ekonomi }\end{array}$ & $\begin{array}{l}\text { Pertumbuhan } \\
\text { Produktivitas }\end{array}$ & $\begin{array}{l}\text { Rata-rata } \\
\text { Gabungan }\end{array}$ \\
\hline Surakarta & 532,825 & 449,204 & 437,319 & 439,407 \\
\hline Boyolali & 593,039 & 517,902 & 800,704 & 578,813 \\
\hline Sukoharjo & 483,906 & 444,939 & 422,257 & 429,719 \\
\hline Karanganyar & 558,771 & 515,424 & 442,807 & 461,006 \\
\hline Wonogiri & 517,461 & 419,439 & 395,266 & 408,701 \\
\hline Sragen & 519,398 & 421,225 & 449,428 & 427,080 \\
\hline Klaten & 510,088 & 422,546 & 468,470 & 435,503 \\
\hline Rata-rata & 530,784 & 456,386 & 464,746 & 447,895 \\
\hline
\end{tabular}

Sumber: Laporan Hasil Penelitian pada Lampiran Perhitungan Proyeksi Besaran UMK Tahun 2006, Perhitungan $3,4,5,6$.

Tabel 3. Besaran UMK 2007 Hasil Perhitungan dengan Modifikasi Model Proyeksi Kota Surakarta dan Kabupaten Karanganyar

\begin{tabular}{lcccc}
\hline \multirow{2}{*}{ Kab.IKota } & \multicolumn{4}{c}{ Besaran UMK (Rp/bulan) } \\
\cline { 2 - 5 } & $\begin{array}{c}\text { Pencapaian } \\
90 \% \text { KHL }\end{array}$ & $\begin{array}{c}\text { Pertumbuhan } \\
\text { Ekonomi }\end{array}$ & $\begin{array}{c}\text { Pertumbuhan } \\
\text { Produktivitas }\end{array}$ & $\begin{array}{c}\text { Rata-rata } \\
\text { Gabungan }\end{array}$ \\
\hline Surakarta & 596.500 & 597.500 & 598.500 & 597.000 \\
Karanganyar & 581.475 & 576.000 & 579.620 & 580.000 \\
\hline
\end{tabular}

Sumber: Laporan Hasil Penelitian pada Lampiran Perhitungan Proyeksi Besaran UMK Tahun 2007, Perhitungan 1 sampai dengan 5. 


\section{Modifikasi Model Proyeksi}

Hasil perhitungan proyeksi besaran upah minimum dengan model modifikasi proyeksi disajikan dalam tabel 3. Perhitungan besaran upah minimum dengan model proyeksi menggunakan dasar perhitungan tahapan pencapaian KHL pada tahun yang sama dengan tahun besaran UMK yang ditentukan, selanjutnya proyeksi dilakukan dengan variabel pertimbangan adalah pertumbuhan ekonomi dan produktivitas. Hasil perhitungan dengan modifikasi model proyeksi ini adalah perhitungan UMK tahun 2007 untuk Kota Surakarta dan Kabupaten Karanganyar, dikarenakan data yang tersedia hanya dua daerah tersebut.

\section{Data Pendukung}

Dalam menghitung besaran upah minimum maka langkah yang pertama kali dilakukan adalah mengumpulkan data yang diperlukan, baru kemudian menghitung proyeksi dengan model yang sudah dibahas di depan. Data tersebut kemudian diproses untuk mensimulasikan dengan mengaplikasian rumus perhitungan yang ada dalam penelitian ini, atau dalam buku pedoman penghitungan upah minimum.

Data untuk menghitung besaran upah minimum, seperti yang telah diurai diatas meliputi upah minimum (UMK) tahun sebelumnya (2004-2005), kebutuhan hidup minimim (KHM) 2005, kebutuhan hidup layak (KHL) 2005-2006, PDRB tahun 20002004, tingkat inflasi 2005, dan produktivitas tenaga kerja. Kesemua data tersebut untuk wilayah se-Subosukawonosraten (Eks Surakarta).

\section{KESIMPULAN}

Hasil penelitian ini berupa rancangan penentuan upah minimum kabupaten/kota seSubosukawonosraten (Eks. Karesidenan Surakarta) yang tertuang dalam bentuk buku pedoman perhitungan. Langkah yang telah dilakukan adalah mensimulasikan draft buku pedoman dan kemudian menjadikannya menjadi buku pedoman baku. Dari apa yang telah dilakukan dalam penelitian ini, dapat disimpulkan sebagai berikut:

\section{Model Penghitungan Besaran Upah Minimum}

Ada tiga model sebagai alternatif perhitungan usulan upah minimum (UMK):

1) Model proyeksi penghitungan besaran upah minimum sesuai dengan Kepmenaker No.1/1999, merupakan proyeksi dengan dua jenis data dasar, yaitu: (1) besaran upah minimum kabupaten/kota satu tahun sebelumnya yang ditetapkan Pemda, dan (2) besaran kebutuhan hidup minimum satu tahun sebelumnya. Perhitungan besaran upah minumum dengan dua jenis data dasar tersebut dengan variabel pertimbangan sebagai berikut: (1) pertumbuhan sektor industri satu tahun sebelumnya, (2) perkembangan kebutuhan hidup minimum satu tahun sebelumnya, dan (3) tingkat inflasi tahun sekarang.

2) Model proyeksi perhitungan besaran upah minimum sesuai dengan Permenaker 17/2005 tentang KHL, yaitu besaran upah minimum didasarkan di antaranya pada tahap pencapaian $\mathrm{KHL}$, pertumbuhan PDRB, produktivitas, dan mempertimbangkan keberadaan sektor marjinal (usaha yang paling tidak mampu). Pada pelaksanaannya, pertim- 
bangan pada usaha tidak mampu ternyata belum dapat dioperasionalkan, maka untuk kepentingan perhitungan dapat diabaikan. Dengan demikian besaran upah minimum dihitung berdasar tahap pencapaian KHL, produktivitas, dan pertumbuhan PDRB

3) Modifikasi model proyeksi, yaitu dengan dasar perhitungan adalah tahapan pencapaian $\mathrm{KHL}$ pada tahun yang sama dengan tahun besaran UMK yang ditentukan. Selanjutnya dengan data dasar pencapaian tahapan KHL tersebut, dilakukan proyeksi besaran UMK dengan variabel pertimbangan adalah pertumbuhan ekonomi dan produktivitas.

\section{Hasil Simulasi Penghitungan Besaran Upah Minimum}

Berdasar model penghitungan besaran upah minimum dengan tiga model tersebut maka dapat disimulasikan dengan data yang dikumpulkan terlebih dulu. Sebagai hasil simulasi yang telah dilakukan, dihasilkan angka besaran upah minimum yang berbedabeda namun nilainya tidak jauh berbeda antara model satu dengan model yang lainnya. Ini berarti bahwa besaran upah minimum sebagai hasil perhitungan adalah akurat, dengan demikian model proyeksi tersebut dapat digunakan sebagai acuan dalam menentukan besaran upah minimum oleh pihak yang terkait, yaitu dewan pengupahan daerah.

\section{Data Pendukung}

Sesuai dengan tujuan dan manfaat dari kegiatan penelitian ini, maka telah dapat diidentifikasi data sosial ekonomi maupun non ekonomi sebagai faktor penentu maupun pertimbangan terhadap penghitungan besaran upah minimum, di antaranya: upah minimum (UMK) tahun sebelumnya (2004-2005), kebutuhan hidup minimum (KHM) 2005, kebutuhan hidup layak (KHL) 2005-2006, PDRB tahun 2000-2004, tingkat inflasi 2005, dan produktivitas tenaga kerja. Kesemuanya data tersebut untuk wilayah seSubosukawonosraten (Eks Surakarta).

\section{DAFTAR PUSTAKA}

Asep Suryahadi dkk. 2003. Kebijakan Upah Minimum dan Dampaknya terhadap Pasar Tenaga Kerja. LP SMERU Paper ISEI ke XV, Malang 13- 15 Juli 2003.

Karanganyar Tahun 2006. Prediksi Upah Minimum Kota (UMK) Surakarta \& Kabupaten Karanganyar Tahun 2007. Makalah Presentasi di Dewan Pengupahan Daerah Kota Surakarta \& Kabupaten Karanganyar, 11 September 2006. Karanganyar Tahun 2006. Makalah Presentasi di Dewan Pengupahan Daerah Kota Surakarta \& Kabupaten Karanganyar, 17 Oktober 2005 .

Keputusan Gubernur Jawa Tengah. Nomor: 561/44/2003. Tentang Upah Minimum pada 35 Kabupaten/Kota di Propinsi Jowa Tengah Tahun 2004.

Kompas. 2004, 17 Nopember. Penerapan Upah Sektoral untuk Menekan Distorsi Pengupahan.

Penelitian DP3M Ditjen Dikti. Jakarta. 2004. Makalah Presentasi Seminar Hasil Penelitian di Dikti 9-1 Mei 2005.

Peraturan Menteri Tenaga Kerja Republik Indonesia No 1 Tahun 1999. Jakarta.

Purwono. 2002. Peran Statistik dalam Penetapan Upah Minimum Perkotaan/ Kabupaten. Makalah disampaikan pada 
Kuliah Umum FE Universitas Sebelas Maret. 15 Oktober 2002. Surakarta: FE UNS.

Rodgers, Gerry. 1994. Workers, Institutions and Economic Growth in Asia. International Institute for Labor Studies Geneva.

Solo Pos, 2003, 1 September. Hari ini Serikat Buruh se Surakarta Bahas $U M K$.

Solo Pos, 2003, 2 September. Apindo: Angka itu tidak Realistis.

Solo Pos, 2003, 4 September. Apapun Hasilnya akan Diajukan ke Propinsi.

Solo Pos, 2004, 1 Oktober. UMK 2005 Boyolali Disepakati Naik 7,3\%.

Solo Pos, 2004, 28 September. Walikota Tetapkan UMK Rp 427.000,-.

Solo Pos, 2005, 2 September. Solo Sepakat Rp 477.755,- Sukoharjo Tertinggi.

Solo Pos, 2005, 21 Oktober. UMK 2006, Sepakat dengan Angka tidak Sama.

Suara Merdeka. 2002, 2 Mei. Ratusan Buruh Geruduk Dewan.
Suparno. 2002. Pengupahan dilihat dari Kacamata Pekerja. Makalah disampaikan pada Kuliah Umum FE UNS.15 Oktober 2002. Surakarta.

Sutomo dan Yunastiti Purwaningsih. 2005. Analisis Penentuan Besarnya Upah Minimum Kabupaten Kota Se-Eks. Karesidenan Surakarta Tahun 2004. Surakarta.

Sutomo, 2005. Prediksi Upah Minimum Kota (UMK) Surakarta \& Kabupaten

Sutomo, 2005. UMK 2006, Sepakat dengan Angka tidak Sama. Solo Pos 21 Oktober 2005.

Undang-Undang Republik Indonesia Nomor 13 Tahun 2003 tentang Ketenagakerjaan. 2003. Jakarta.

Wachtel, Howard M.. 1984. Labor and the Economy. Third Edition. Harcourt Brace Jovanovich: The Dryden Press.

www.nakertrans.go.id. Situs resmi Departemen Tenaga Kerja Transmigrasi RI.

www.bps.go.id. Situs Resmi Badan Pusat Statistik.

www.kompas.co.id. Situs Resmi Kompas. 